${ }^{9}$ Koffler, D, and Paronetto, F, American fournal of Pathology, 1966, 49, 383.

10 Ben-Ishay, Z, Israel fournal of Medical Sciences, 1967, 3, 191.

11 Clarkson, A R, et al, Quarterly fournal of Medicine, 1970, 39, 585.

${ }^{12}$ McKay, D G, in Thrombosis et Diathesis Haemorrhagica, 1969.

13 Astrup, T, and Mullertz, S, Archives of Biochemistry and Biophysics, 1952, 40, 346.

14 Ekelund, H, Hedner, U, and Astedt, B, Acta Paediatrica Scandinavica, $1970,59,369$.

15 Garvey, M B, and Black, J M, Fournal of Clinical Pathology, 1972, 25, 680.

${ }^{16}$ Gram, H C, Fournal of Biological Chemistry, 1921, 49, 279.

${ }^{17}$ Colman, R W, Robboy, S J, and Minna, J D, American fournal of Medicine, 1972, 52, 679.

18 Oken, D E, Nephron, 1971, 8, 505.

19 Earley, L E, New England fournal of Medicine, 1970, 282, 1370.
20 Lancet, 1973, 2, 134.

21 Vassalli, P, and Richet, G, in Proceedings of the First International Congress. of Nephrology, ed G Richet, p 236. Basel, Karger, 1961.

22 Wardle, E N, and Wright, N A, Archives of Pathology, 1973, 95, 271.

${ }^{23}$ Bonnar, J, McNicol, G P, and Douglas, A S, British Medical fournal, 1969, 3, 387.

${ }^{24}$ Charytan, C, and Purtilo, D, New England fournal of Medicine, 1969, 280, 1102.

25 Norman, P S, fournal of Experimental Medicine, 1958, 108, 53.

${ }^{26}$ Astrup, T, Thrombosis et Diathesis Haemorrhagica, suppl 54, p 83.

27 Lancet, 1974, 2, 1430.

${ }^{28}$ Naeye, R L, New England fournal of Medicine, 1961, 265, 867.

29 Howie, P W, et al, Lancet, 1970, 2, 1329.

${ }^{30}$ Bergstein, J M, and Michael, A F, Fournal of Laboratory and Clinical Medicine, 1972, 79, 701.

\title{
Secretion of immunoreactive calcitonin by human breast carcinomas
}

\author{
R C COOMBES, G C EASTY，S I DETRE，C J HILLYARD，U STEVENS，S I GIRGIS, \\ L S GALANTE, L HEYWOOD, I MACINTYRE, A M NEVILLE
}

non-endocrine tumours, including a squamous-cell carcinoma of the bronchus and seven out of eight consecutive breast carcinomas. ${ }^{5}$ The latter association is of particular interest since patients with breast carcinoma may have high levels of circulating immunoreactive calcitonin. ${ }^{6}$

\section{Summary}

Twenty-three out of 28 patients with metastatic breast carcinoma and one out of 13 patients with localised disease had raised levels of plasma immunoreactive calcitonin. Monolayer cultures of breast carcinomas maintained for up to 10 weeks released immunoreactive calcitonin, and a primary breast carcinoma passaged in "nude" mice for over a year contained material immunologically and chromatographically resembling the monomeric form of human calcitonin.

These studies indicate that breast carcinomas can produce calcitonin and that plasma calcitonin measurements may be useful in staging patients with breast carcinomas.

\section{Introduction}

Extrathyroidal secretion of calcitonin has been suggested by finding increased concentrations of immunologically or biologically active hormone in a variety of endocrine tumours ${ }^{1-3}$ and an oat-cell carcinoma of the bronchus. ${ }^{4}$ Using extraction procedures we have detected immunoreactive calcitonin in

\footnotetext{
Unit of Human Cancer Biology, Ludwig Institute for Cancer Research and Royal Marsden Hospital, London

R C COOMBES, MRCP, MRC clinical research fellow

G C EASTY, PHD, senior grade scientist

$S$ I DETRE, BSC, junior technical officer

U STEVENS, technical officer

A M NEVILLE, MD, MRCPATH, professor of experimental pathology

Endocrine Unit, Royal Postgraduate Medical School, Hammersmith

Hospital, London W12 0HS

C J HILLYARD, BSC, scientific officer

$S$ I GIRGIS, $\mathrm{MB}, \mathrm{BCH}$, honorary research assistant

L S GALANTE, PHD, honorary assistant lecturer

L HEYWOOD, junior technician

I MACINTYRE, PHD, FRCPATH, professor and director of unit
}

This observation, and the urgent need for a satisfactory marker for breast cancer, ${ }^{7}$ prompted us to carry out studies in vitro and in vivo to establish whether calcitonin is actually produced by breast carcinomas, and not simply stored or adsorbed by them. We also wanted to determine whether calcitonin estimations could be useful in the staging of this disease.

\section{Patients and methods}

Fasting venous blood samples were obtained from 72 patients with breast disease. The samples were placed on ice and immediately centrifuged for 10-20 minutes, and the plasma was separated and stored at $-20^{\circ} \mathrm{C}$ until immunoassay, which was within two weeks of collection.

Thirty-five consecutive patients were awaiting surgery at the Royal Marsden Hospital, 17 consecutive patients were attending the radiotherapy department of Hammersmith Hospital for postoperative radiotherapy, and the remaining 20 patients were inpatients on the radiotherapy wards. All except two were normocalcaemic and were not suffering from renal failure, liver failure, or any other form of malignant or endocrine disease known to be associated with hypercalcitoninaemia.

Each patient was placed in one of four groups depending on the histology of the tumour removed and the presence or absence of distant metastases as disclosed by full biochemical profile, bone and liver scans, bone marrow aspiration, and skeletal survey. Fourteen patients had benign disease, 13 had cancer localized to breast and lymph nodes, 17 were recovering from mastectomy, and 28 had metastatic disease. Those patients from whom samples were obtained three to four weeks after mastectomy had no evidence of metastatic disease as determined by these criteria. The control group of 69 patients has been described. ${ }^{6}$

\section{PREPARATION OF MONOLAYER CULTURES OF BREAST CARCINOMAS}

Twenty-one consecutive breast tumours were studied: 15 were histologically proved carcinomas and six were fibroadenomas (see table). Tumour tissue, removed at operation, was immediately placed in medium 199 (Bio-Cult Labs) containing 0.05\% penicillin and 
$0.05 \%$ streptomycin and delivered to the laboratory within two hours. Contaminating fat and connective tissue were removed. The remaining tumour was cut into $0.5-\mathrm{mm}$ slices which were then reduced to a fine "mince," transferred to a sterile centrifuge tube containing medium 199, shaken manually for five minutes, and then allowed to stand for five minutes. The supernatant containing single and small aggregates of cells was removed with a Pasteur pipette, transferred to a 25-ml Falcon flask, and incubated with 5-ml medium RPM1 1640 with $10 \%$ fetal calf serum at $37^{\circ} \mathrm{C}$. When the cells had attached (within three days) they were rinsed with medium RPM1 1640 containing $10 \%$ lamb serum and refed with this medium, which was replaced every two or three days. The cell-exposed media were stored at $-30^{\circ} \mathrm{C}$ for subsequent calcitonin immunoassay. Selected cultures $(1,2$, and 3 , see table) were incubated for 24 hours with $10-\mathrm{mM}$ dibutyryl cyclic adenosine monophosphate (AMP) (Sigma) or calcium chloride $(7.5 \mathrm{mmol} / 1(15 \mathrm{mEq} / \mathrm{l}))$.

\section{CULTURE OF BREAST TUMOURS IN IMMUNE-DEFICIENT MICE}

Athymic nude mice (obtained from the MRC Laboratory Animal Centre, Carshalton, and Anglia Laboratory Animals) were delivered to our laboratory pathogen-free and were housed in a sterile environment.

A breast tumour (grade 2, infiltrating and intraduct carcinoma) was obtained at operation, and blocks $2 \times 2 \times 3 \mathrm{~mm}$ were implanted subcutaneously into four sites of four female nude mice. These xenografts grew to an average size of $1 \mathrm{~cm} .^{3}$ One mouse was killed seven months after the original implant and a $2 \times 2 \times 3-\mathrm{mm}$ sample from each graft site was implanted into another nude mouse. After five months further growth had occurred and the tumour was removed and extracted with $0 \cdot 1-\mathrm{M} \mathrm{HCl}^{8}$ Control mouse salivary gland and thyroid tissue from 11 BALB-C mice were extracted in a similar manner. A monolayer culture of some of the mouse-grown breast tumour was prepared (see above) and the medium immunoassayed for calcitonin, after incubation with the cells for three days.

\section{CHROMATOGRAPHY}

Media from breast carcinoma cultures 9 and 11 (see table) were collected over a week, pooled, and lyophilised after removing material of less than 1000 molecular weight by filtration using AMICON UM2 filters. This material and an extract of mouse-grown breast tumour and control mouse tissue were chromatographed using a G50 Sephadex column $(130 \times 1 \mathrm{~cm})$ equilibrated with $0 \cdot 1-\mathrm{M}$ formic acid and $10 \%$

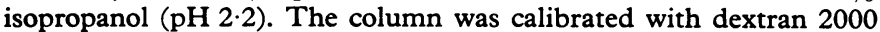
and ${ }^{125}$ I-labelled synthetic human calcitonin. Fractions were collected at room temperature, lyophilised, and dissolved in $0.05-\mathrm{M}$ phosphate buffer before immunoassay.

\section{IMMUNOASSAY}

The immunoassay for plasma calcitonin using an antiserum directed against synthetic human calcitonin has been reported elsewhere. ${ }^{6}$ The immunoassay for carcinoembryonic antigen (CEA) has also been described, ${ }^{9}$ and the method for human chorionic gonadotrophin (HCG) immunoassay was that of Vaitukaitis et al, ${ }^{10}$ but using Burroughs-Wellcome antiserum RD01. Insulin was measured using a kit (Gruppo Lepetit, Italy).

For tissue culture samples, similar methods were followed but unincubated tissue culture medium was used in the standard curve in the place of plasma. Control culture medium from fibroblasts, incubated under similar conditions to the breast carcinomas, was included in each immunoassay; all samples were assayed in duplicate and in at least two dilutions.

\section{Results}

\section{PLASMA IMMUNOREACTIVE CALCITONIN IN PATIENTS}

Immunoreactive calcitonin was undetectable $(<0 \cdot 1 \mu \mathrm{g} / \mathrm{l})$ in plasma samples from our control population of 69 subjects $^{6}$ and in the plasma of 14 patients with benign breast disease. Only one of 13 patients with apparently localised disease and three out of 17 patients who had had "curative" mastectomy had raised plasma calcitonin levels. One of the

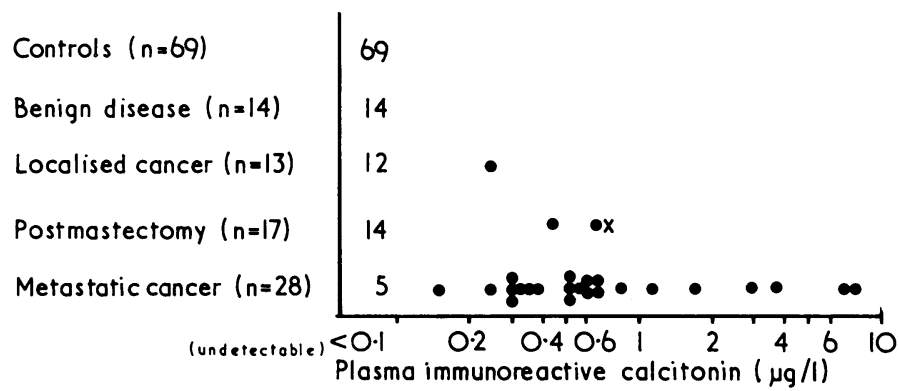

FIG 1-Plasma calcitonin in patients with breast disease. $x=$ Patient who developed metastases three months after sample was taken.

latter subsequently developed distant metastases. In contrast, 23 out of 28 patients with metastatic disease had high levels of circulating immunoreactive calcitonin (fig 1).

\section{BREAST TUMOUR MONOLAYER CULTURES}

Within three to four days clusters of epithelial cells had settled on the plastic substrate of the Falcon flasks. Significant proliferation of the cultures of epithelial cells was rarely observed, but all cultures survived for at least two weeks and three survived for four to 10 weeks before overgrowth by fibroblasts occurred (see table).

Eight out of 15 cultures of breast carcinoma cells released a material which, in at least two dilutions, inhibited the binding of ${ }^{125} \mathrm{I}$-labelled calcitonin to antibody in a similar manner to synthetic human calcitonin. In contrast, immunoreactive material was not detected in media from fibroadenoma or fibroblast cultures which were incubated under identical conditions.

Three cultures continued to release hormone for four, six, and ten weeks respectively. In these cultures the rate of production of immunoreactive calcitonin was not altered by incubation with $10-\mathrm{mM}$ dibutyryl cyclic AMP or by increasing the calcium concentrations of the medium incubated with the cells. Two out of six breast carcinomas also produced a material which inhibited the binding of ${ }^{125}$ I-labelled CEA to anti-CEA, and three out of 12 released immunoreactive HCG. Immunoreactive insulin was not detected in any of the three cultures tested $(\mathrm{N} 1,2$, and 3$)$.

Gel filtration of medium incubated with breast carcinoma cultures 9 and 11 showed that some immunoreactive material was eluted at a similar position to ${ }^{125} \mathrm{I}$-labelled calcitonin, some eluted before, and some later, indicating the presence of multiple immunoreactive forms.

TABLE I-Breast tumour monolayer cultures

\begin{tabular}{|c|c|c|c|c|c|}
\hline \multirow[b]{2}{*}{$\begin{array}{l}\text { Culture } \\
\text { No. }\end{array}$} & \multirow[b]{2}{*}{ Tumour* } & \multirow{2}{*}{$\begin{array}{c}\text { Time } \\
\text { over } \\
\text { which } \\
\text { calcitonin } \\
\text { was } \\
\text { measured } \\
\text { (weeks) }\end{array}$} & \multirow{2}{*}{$\begin{array}{c}\text { Maximum } \\
\text { calcitonin } \\
\text { concentration } \\
(\mu \mathrm{g} 1 \text { medium } \\
\left.24 \mathrm{~h}^{-1}\right)\end{array}$} & \multicolumn{2}{|c|}{ Other products measured } \\
\hline & & & & $\underset{\left(\mu \mathrm{g} 1^{-1} 24 h^{-1}\right)}{\text { CEA }}$ & $\underset{\left(\mathrm{U}^{-1} 24 \mathrm{~h}^{-1}\right)}{\mathrm{HGG}}$ \\
\hline \begin{tabular}{|l|}
1 \\
2 \\
3 \\
4 \\
5 \\
6 \\
7 \\
8 \\
9 \\
10 \\
11 \\
12 \\
13 \\
14 \\
15 \\
$16-21$
\end{tabular} & $\begin{array}{l}\text { Carcinoma } \\
\text { Carcinoma } \\
\text { Carcinoma } \\
\text { Carcinoma }{ }^{-} \\
\text {Carcinoma } \\
\text { Carcinoma } \\
\text { Carcinoma } \\
\text { Carcinoma } \\
\text { Carcinoma } \dagger \\
\text { Carcinoma } \\
\text { Carcinoma } \\
\text { Carcinoma } \\
\text { Carcinoma } \\
\text { Carcinoma } \\
\text { Carcinoma } \\
\text { Fibro- } \\
\text { adenomas }\end{array}$ & $\begin{array}{r}10 \\
4 \\
6 \\
2 \\
2 \\
2 \\
2 \\
2 \\
1 \\
2 \\
1 \\
2 \\
2 \\
2 \\
2 \\
2\end{array}$ & $\begin{array}{l}1 \cdot 2 \\
1 \cdot 0 \\
0 \cdot 76 \\
\text { ND } \\
\text { ND } \\
\text { ND } \\
1 \cdot 25 \\
\text { ND } \\
0 \cdot 92 \\
1.28 \\
0.16 \\
1 \cdot 0 \\
\text { ND } \\
\text { ND } \\
\text { ND } \\
\text { ND }\end{array}$ & $\begin{array}{l}\text { ND } \\
\text { ND } \\
66 \\
\text { ND } \\
\text { ND }\end{array}$ & $\begin{array}{l}\text { ND } \\
1 \cdot 6 \\
\text { ND } \\
\text { ND } \\
20 \\
\text { ND } \\
\text { ND } \\
8 \cdot 6 \\
\text { ND } \\
\text { ND } \\
\text { ND } \\
\text { ND } \\
\text { ND (2) }\end{array}$ \\
\hline
\end{tabular}

*Unless otherwise stated all carcinomas were infiltrating ductal carcinomas. $\dagger$ Mucus-secreting carcinomas. \pm Medullary carcinoma.

\section{BREAST TUMOUR GROWN IN NUDE MICE}

The breast xenograft studied had an identical histological appearance to the specimen removed from the patient at operation one year 
earlier. The extract contained a material ( $20 \mathrm{ng} / \mathrm{g}$ wet tissue) which, in six dilutions, paralleled the standard curve of synthetic human calcitonin (fig 2b) in the immunoassay. When chromatographed, the immunoreactive material eluted as two peaks, one running before and one coincident with ${ }^{125}$ I-labelled calcitonin (fig 3). An extract of control mouse tissue was similarly chromatographed, but no peak of immunoreactivity was found. The extract of mouse thyroid glands contained a material which, in several dilutions, inhibited the binding of ${ }^{125} \mathrm{I}$-labelled calcitonin to antibody, but, in contrast to the xenograft extract, this inhibition did not parallel that produced by the synthetic standard (fig 2a). Subsequently monolayer culture of this tumour was shown to release a material which resembled synthetic human calcitonin immunologically (3-5 $\mu \mathrm{g} 1$ tissue culture medium ${ }^{-1}$ day $\left.^{-1}\right)$.

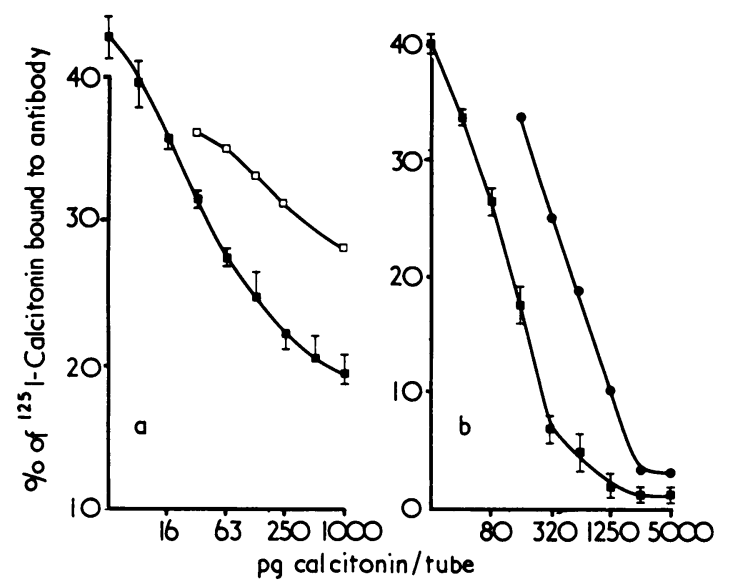

FIG 2-Comparison of displacement of ${ }^{125}$ I-labelled calcitonin from antibody by synthetic human calcitonin ( $\square-\square)$ and by (a) mouse thyroid extract $(\square-\square)$, and (b) mouse-grown human breast carcinoma extract ( - ).

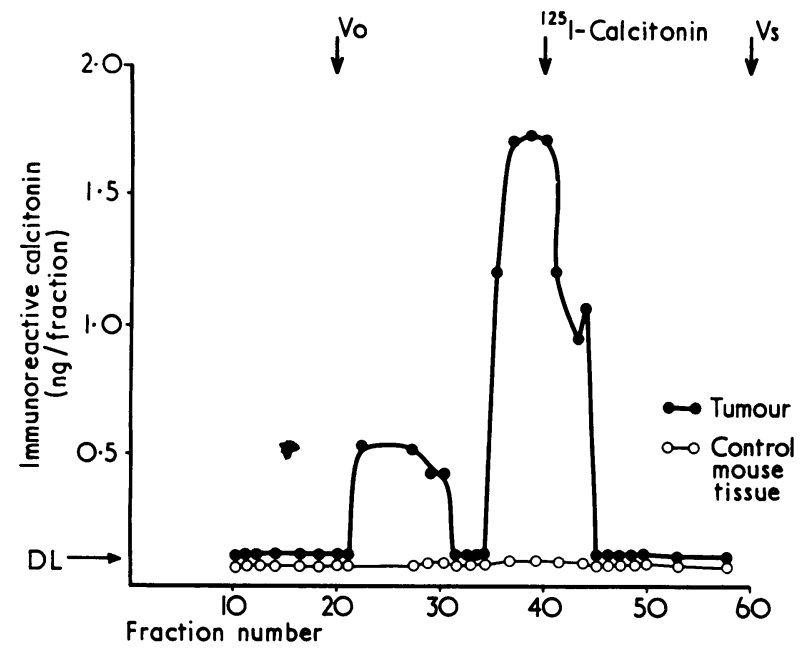

FIG. 3-G50 elution pattern of extract of human breast tumour grown in nude mouse. $\mathrm{DL}=$ Detection limits of assay. $\mathrm{Vo}=$ Exclusion volume. $\mathrm{Vs}=$ Salt volume.

\section{Discussion}

Many plasma constituents circulate in abnormally high concentrations in patients with advanced malignancies. Most often these represent secondary effects of the tumour on normal tissues, but occasionally they represent release of substances by the neoplastic cell.?

Our results indicate that in the case of the association of breast carcinomas with calcitonin the tumours themselves produce calcitonin. This is shown by the release of immunoreactive calcitonin by eight out of 15 consecutive breast carcinoma monolayer cultures for up to 10 weeks and by the ability of a human breast carcinoma to release calcitonin after prolonged culture in immune-deficient mice. Calcitonin from this tumour resembled human calcitonin $M$ and not mouse calcitonin, indicating that a "sponge" phenomenon" in which circulating calcitonin is adsorbed by the tumour could not account for our findings.

Other methods of showing hormone production by tumours, such as the measurement of an arteriovenous difference of hormone concentration across a tumour bed or incorporation of labelled amino-acids into peptide by tumour cells could be applied to calcitonin production by breast cancer. We believe, however, that the former method may lead to misleading results owing to fluctuation in levels, intermittent release of adsorbed products, and intra-assay variation. Difficulty in isolating and satisfactorily identifying a peptide after labelled amino-acid incorporation and the problems of ensuring adequate controls make the latter method even more difficult to achieve with any degree of reproducibility.

Using culture methods, we have shown for the first time that short-term monolayer culture systems of breast carcinoma can release peptides, and that immune-deficient mice can support not only the growth of human breast tumours but also the production of a peptide by this tumour. This is important for those investigating the functional pathology of tumours, since these culture systems could be of value in studying tumour products and further clarifying their relationship to tumour mass, suggested here by finding raised circulating levels in those patients with metastatic disease. Although the clinical data suggest that plasma calcitonin estimations may be useful in staging breast carcinoma patients, all except four of those with raised levels had metastatic disease which was evident clinically or on investigation. Furthermore, as is the case for several other possible markers for breast carcinoma, such as $\mathrm{CEA}^{12}$, casein, ${ }^{13}$ and HCG, ${ }^{14}{ }^{15}$ the test is not specific for breast carcinoma.

The data obtained from the monolayer cultures indicate, however, that an approach involving the use of several markers may well be valuable since these studies show that some tumours can secrete calcitonin, while others secrete HCG or CEA.

We thank Mr J-C Gazet, Dr T Powles and Dr H T Ford of the Royal Marsden Hospital, Sutton, and the consultants of the radiotherapy department, Hammersmith Hospital, for permission to study patients under their care.

These investigations were supported by programme and project grants from the Medical Research Council to IM and AMN. They were also supported by the Ludwig Institute for Cancer Research and the Wellcome Trust. RCC is in receipt of a Medical Research Council clinical research fellowship. We gratefully acknowledge the technical help of Miss T Billingsley.

Requests for reprints should be sent to RCC.

\section{References}

1 Milhaud, G, et al, Comptes Rendus Hebdomadaires des Séances de l'Académie des Sciences, 1970, 29, 8775.

2 Milhaud, G, et al, in Calcium, Parathyroid Hormone and the Calcitonins, ed R V Talmage and P L Munson, p 56. Amsterdam, Excerpta Medica, 1972.

3 Voelkel, E F, et al, fournal of Clinical Endocrinology and Metabolism, 1973, 37, 297.

${ }^{4}$ Silva, O L, et al, New England Fournal of Medicine, 1974, 290, 1122.

5 Hillyard, C J, et al, Clinical Endocrinology, in press.

6 Coombes, R C, et al, Lancet, 1974, 1, 1080.

7 Neville, A M, and Cooper, E H, Annals of Clinical Biochemistry, in press.

${ }^{8}$ Roos, B A, Okano, K, and Deftos, L J, Biochemical and Biophysical Research Communications, 1974, 60, 1134.

9 Laurence, D J R, et al, British Medical fournal, 1972, 3, 605.

10 Vaitukaitis, J L, Braunstein, G D, and Ross, G T, American fournal of Obstetrics and Gynecology, 1972, 113, 751.

11 Unger, R H, Lochner, J V, and Eisentraut, A M, fournal of Clinical Endocrinology, 1964, 24, 823.

$12 \mathrm{Chu}, \mathrm{T} \mathrm{M}$, and Nemoto, T, Fournal of the National Cancer Institute, 173, $51,1119$.

${ }^{13}$ Hendrick, J C, and Franchimont, P, European fournal of Cancer, 1974, 10,725 .

14 McArthur, J W, Progress in Obstetrics and Gynaecology, vol IV, p 146. Heinemann, London, 1963.

${ }^{15}$ Braunstein, G D, et al, Annals of Internal Medicine, 1973, 78, 39. 